\title{
Is parliamentary attention to the EU strongest when it is needed the most? National parliaments and the selective debate of EU policies
}

Thomas Winzen, School of Social Sciences, University of Mannheim, Mannheim, Germany

Rik de Ruiter, Institute of Public Administration, Leiden University, Den Haag, The Netherlands

Jofre Rocabert, Center for Comparative and International Studies, ETH Zurich, Zurich, Switzerland

\begin{abstract}
When do parliaments debate European Union policies? Normative arguments suggest that debates enhance government accountability. Others warn of government bias, declining debate near elections, and parties avoiding Eurosceptic publics. Our conclusions are more differentiated. We argue that rank-and-file parliamentarians rather than leaders initiate debates. Political incentives guide their debate selection towards salient policies in the countries in which voters care most. However, where the motivation Eurosceptic publics provide and institutions facilitating rank-and-file agenda-setting are lacking, EU law-making and European Council priorities will raise little parliamentary attention. Analysis of original data, using a Bayesian and multilevel framework, lends credibility to our views. Claims of a government bias, election effects, or trends towards more debate are unlikely to hold in all countries.
\end{abstract}

Keywords: European Union, national parliaments, parliamentary debate, political parties

Corresponding author: Thomas Winzen, School of Social Sciences, University of Mannheim, A5, 6, 68131 Mannheim, Germany.

Email: winzen@uni-mannheim.de. 


\section{Introduction}

When and why do we observe parliamentary debates about the policies of the European Union (EU)? De Wilde and Raunio (2015) make the normative argument that parliamentary debate is most needed in the EU's salient core state policies-the policies that have drawn the European Council ever more into the details of policy-making and dominated public controversy on European integration post-Maastricht (Bickerton et al., 2015; Hooghe and Marks, 2009). In these areas, debates are of greatest relevance for interested audiences. Here, parliaments could indeed enhance public information and even governmental accountability, as some scholars suggest (Auel and Raunio, 2014b; Auel et al., 2015; Bellamy and Kröger, 2016; Rauh and De Wilde, 2018; Hoerner, 2017; Senninger, 2017). Yet, can we expect parliaments to direct their attention in this way?

We explain our argument based on the two most ambitious studies to date. This is not to deny the importance of many qualitative and case studies (Auel and Raunio, 2014a; Kinski, 2016; Wendler, 2014). However, these studies do not tell us the conditions of debate over many years, parties, and countries. In their investigation of EU debate in 27 parliaments, Auel and colleagues (2015) find that institutional resources, such as information rights, best explain debate, although Eurosceptic parties and Eurozone membership matters as well. Investigating debates in four countries over 20 years, Rauh and de Wilde (2018) likewise conclude that institutional resources matter. They also find a systematic relationship between debates, European Council summits, and EU directives. Yet, they urge caution regarding the accountability potential of debates based on the result that governments are mostly responsible for EU debates, and that parties talk less about the EU near elections and to Eurosceptic publics.

Our argument differs in some critical respects. We agree that institutional resources and Euroscepticism constitute essential political context. Yet, we consider Euroscepticism a positive motivation to engage in debates on the EU rather than a reason to avoid debate (see e.g. Finke and Dannwolf, 2013; Gattermann and Hefftler, 2015; Williams, 2016). We share the view that debates follow European Council meetings and EU laws, albeit in a highly contingent way. First, we contend that this relationship only exists where Euroscepticism and institutional resources provide parliamentarians with the necessary motivation and capacity (for a similar argument on the use of the early warning system, see Gattermann and 
Hefftler, 2015). Second, the policy context has been downplayed in the literature (but see de Ruiter, 2013; Finke and Dannwolf, 2013). Yet, EU laws are likely to attract more routine attention in the EU's regulatory policies in which the Union's legislative importance is widely understood. In core state policies, debate is likely to focus on the more visible controversies surrounding the European Council agenda.

Central to our reasoning is the view that few actors in parliament are strongly interested in EU debates. For party leaders, multidimensional wedge issues are unappealing since they hinder the articulation of the party message (de Vries and Hobolt, 2012; Green-Pedersen, 2012; Hobolt and de Vries, 2015). We focus on backbenchers' interests. Yet, even though many studies suggest that rank-and-file politicians predominantly shoulder the burden of EU monitoring (for a review, see e.g. Raunio, 2009), the motivational and institutional hurdles for EU debate are high, and will only be overcome where extra-parliamentary contestation and intra-parliamentary monitoring of the EU is already significant.

If the political context is right, parliamentarians will nonetheless choose their debates carefully. Prominent European Council summits are likely to attract their attention more than the less visible law-making process. This is likely to be the case in particular in sovereignty-sensitive core state policies in which politicians are more concerned with principled arguments about the desirability of European competences than the minutiae of legislative scrutiny (Genschel and Jachtenfuchs, 2014a).

Empirically, we introduce new, hand-coded debate data on five countries over 10 years. This data complements available cross-sectional data (Auel et al., 2015) and dictionary-based longitudinal data (Rauh and De Wilde, 2018). It incorporates additional information on the policy areas of EU debate and agenda-setting parties. Furthermore, we offer a disaggregated and multilevel analysis in a Bayesian framework compared to recent pooled and crosssectional studies.

The results lend credibility to key parts of our argument. In the absence of Euroscepticism and institutional capacity, countries experience very little parliamentary EU debate. Where these conditions exist, parties pay systematic attention to EU law-making and the European Council. Regulatory policies and high institutional capacity seem to be particularly conducive to debates on EU law proposals and, less clearly, adopted EU directives. Core state policies and high Euroscepticism especially encourage attention to the European Council. Claims as 
to a government bias, declining debate near elections, the relevance of intra-party dissent, or the existence of a long-term trend towards more debate may be valid in some but not all countries.

\section{Parties, backbenchers and parliamentary debate on the EU}

Our explanation of parliamentary EU debate focuses on the incentives of rank-and-file parliamentarians. The reason is the prevalent view that party leaders are unlikely initiators of many EU debates. Scholars conceptualize EU related topics as wedge issues that cross-cut the political space (Hobolt and de Vries, 2015; de Vries and Hobolt, 2012; Green-Pedersen, 2012; König et al., 2017). The multidimensional character of EU topics makes them ill-suited for the communication of parties' messages to voters and coalition partners (de Vries and Hobolt, 2012; Green-Pedersen, 2012; Hobolt and de Vries, 2015). Hence, Green-Pedersen (2012) argues that EU debates are unlikely first choices of most party leaders. We do not rule out that this could be different for Eurosceptic challengers (e.g. Auel et al., 2015; Hoerner, 2017; Senninger, 2017). Yet, our interest, following demands in the literature (Green-Pedersen, 2012; Hutter and Grande, 2014), lies with the centrist parties for which EU debate is more puzzling.

Leadership disinterest does not automatically imply backbench relevance. Yet, all parliamentary parties divide work between leaders and other parliamentarians. For theories of legislative organization, this division is understood as an exchange (e.g. Strøm, 1998; Martin, 2014). Leaders entrust policy monitoring to group members in committees. In return for the costly monitoring effort, the rank-and-file obtain privileges in their area. These, we suggest, include the right to speak on a policy in parliament, and thus to reap visibility and reputation gains. Consequently, most parliamentary debate will reflect policy specialists' concerns and the policy agendas that they encounter in their domains.

We by no means maintain that this mechanism applies to all situations but it describes the case of EU affairs. Empirical evidence suggests that already by the late 1990s the monitoring of EU affairs had become the task of policy specialists in the parliamentary parties and committees. All member state parliaments had detailed procedures for the scrutiny of the EU in standing committees (e.g. Bergman, 1997; Raunio, 2009; Winzen, 2012). Even 
parliaments such as the British House of Commons, reputed for weak specialization (André et al., 2016), had committees and elaborate rules for EU monitoring (e.g. Carter, 2001).

By leaving the EU to the party rank-and-file, party leaders make them the principal reservoir-and explanatory starting point-for EU debates. This does not rule out occasional leadership attention to the EU. For instance, plenary debates after the biannual European Council summits are common across the EU. These debates are overdetermined by leadership and rank-and-file demands and parliamentary rules. We certainly also expect debates on major events such as treaty reforms (Rauh and De Wilde, 2018). However, our goal is not to explain the one salient debate that follows a European Council meeting but rather regular parliamentary engagement with the EU's legislative and policy agenda, over many debates and policy areas. We need to understand who, in parliament, could be interested in EU affairs on a regular basis. This is why we emphasize the rank-and-file more than party leaderships.

\section{Policy choice: Which EU topics for the plenary?}

The expectation that backbenchers pay most attention to EU affairs neither explains which EU topics they would consider interesting, nor whether they have the motivation or institutional resources to initiate debates.

For rank-and-file parliamentarians, not all EU topics are worth their plenary time. Yet, they cannot always ignore the EU without inviting criticism of their policy literacy. This leads existing studies to the plausible expectation that salient EU policy and legislative developments are most likely to trigger parliamentary debate, since the rank-and-file cannot ignore them and are likely aware of them. Likely candidates for more regular parliamentary attention are the European Council agenda and proposed and adopted EU directives (e.g. Rauh and De Wilde, 2018). These inputs could plausibly explain selective parliamentary attention to some policies rather than others, since the European Council's priorities (Alexandrova et al., 2014) and EU law-production vary across policies (e.g. Franchino and Hoyland, 2009).

In addition, we suspect that the relative importance of the European Council and EU lawmaking differs across policy domains. We distinguish regulatory and core state policies (Genschel and Jachtenfuchs, 2014b). Core state policies are historical state monopolies and 
symbolically relevant for national sovereignty, such as justice and budgetary matters. Regulatory policies are the Union's market-making and market-flanking competences, such as the internal market, consumer protection, or environment. The European Council and the legislative process could inspire parliamentary debate in both. However, legislators might pay more attention to the European Council in core state policies and to legislation in regulatory policies.

In regulatory policies, there is a large and consolidated body of EU law that parliamentarians cannot ignore without having their policy literacy questioned. For instance, MPs cannot afford neglecting internal market legislation (e.g. the services directive), which often impacts visibly on the economic well-being of citizens and companies. In these areas, the fact that the EU is one of the most important sources of rule-making is well-understood. Parliamentarians working on regulatory policies are likely to routinely pay attention to the Union's legislative output and the potential need for debating this output in plenary.

In core state policies, both EU legislation and European Council attention could encourage debate. Certainly, one could imagine particularly sensitive reactions of parliamentarians when the EU prescribes rules in these areas through legislation. Yet, in our view, an alternative hypothesis that suggests greater attention to the European Council and less to legislation makes more sense. There are two reasons for this. First, in areas such as internal security, monetary policy or taxation, the legislative activity of the EU can in fact be quite indirect and subtle once we look beyond isolated, salient examples such as the European Arrest Warrant (Genschel and Jachtenfuchs, 2011; Herschinger et al., 2011). These laws could go unnoticed by parliamentarians.

The second and more important reason that the European Council might affect debate more than EU legislation in core state policies is the visibility of the European Council in core state policies. Parliamentarians are likely to be attracted by the salient conflicts over European integration that have dominated post-Maastricht debates in core state policies (Hooghe and Marks, 2009). The main arena of these debates has been the European Council rather than the ordinary legislative procedure (Bickerton et al., 2015). This does not mean that rank-andfile politicians disregard legislation entirely but that the European Council will attract their attention more reliably. In addition, if party leaders are on occasion interested in EU debates, core state policies debated in the European Council are the most likely candidates. 
We summarize these arguments in two hypotheses:

H1: The more directives the EU proposes $(H 1.1)$ and adopts $(H 1.2)$ in a policy area, the more EU debates parties initiate in that policy area, especially in regulatory policies.

H2: The greater the European Council's attention to a policy area, the more EU debates parties initiate in that policy area, especially in core state policies.

\section{Political context: Backbenchers' agenda-setting motivation and capacity}

Legislative activity and the European Council could interest rank-and-file parliamentarians. Yet, what motivates and enables them to act on these opportunities? We suggest crossnational differences in motivation and capacity.

Since politicians will focus their debates on topics contested in the electorate, we conceive of motivation in terms of Euroscepticism. In many member states, EU membership remains uncontested. Yet, in some countries such as Britain Eurosceptic voters trigger conflicts over European integration. In more Eurosceptic countries, it is plausible that parliamentarians perceive public interest in their stances on EU laws and policies. Elsewhere, it is not only unclear whether backbenchers have anything to gain from EU debates in terms of their visibility and reputation. It is not certain that they even care to monitor EU affairs if voters never inquire as to their stances on the Union's activities.

We conceive of the agenda-setting capacity of the rank-and-file in terms of institutions. While one should consider the agenda-setting rights of leaders and followers (Proksch and Slapin, 2012), we also stress rules and procedures that help parliamentarians acquire information on EU policy-making ('information resources'). We will return to agenda-setting rules in the case selection. Information resources are important since the default focus of party politicians is likely to be on domestic rather than EU issues. Formal monitoring procedures and information flows play a crucial role in generating attention. Institutional capacity thus means the regular supply of EU information to the rank-and-file through strong oversight procedures existing in some parliaments (e.g. Winzen, 2012). Plausibly, variation in these procedures has been found to correlate with the extent of EU debate (Auel et al., 2015; Rauh and De Wilde, 2018). 
Motivation and capacity are not simply additional explanations alongside EU directives and European Council attention. They constitute the necessary political context, in the absence of which parliamentarians lack the willingness, ability and awareness required to act on their opportunities for EU debates. This still leaves parliaments with the kind of over-determined debates mentioned earlier-following key events such as treaty changes or biannual European Council summits. The complete absence of debate should not be expected. However, where willingness and capacity are missing, parliamentary EU debate lacks intraparliamentary advocates.

H3: In the absence of motivation and institutional capacity, the amount of EU directives in (H1.1 and H1.2) and European Council attention to (H2) a policy area, does not systematically relate to the number of EU debates a party initiates in that policy area.

\section{Case selection}

Our analysis relies on data from Austria (AT), Germany (DE), the Netherlands (NL), Spain (ES), and the United Kingdom (UK). Figure 1 (a) shows cross-national variation in political motivation and institutional capacity. We measure Euroscepticism as the share of citizens considering EU membership a 'bad thing' minus 'a good thing' based on Eurobarometer data. We operationalize institutional capacity by using an existing index of the strength of EU oversight institutions in member state parliaments (Winzen, 2012). ${ }^{1}$

\section{---Figure 1---}

In addition to the information in Figure 1, we draw on Proksch and Slapin (2012) who show that speaker selection rules matter. Rules that empower the rank-and-file to act on their debate opportunities could encourage EU debate. Selection rules are themselves manifestations of electoral incentives (Proksch and Slapin, 2012: 528). This reasoning suggests more EU debate in the UK and in Germany, due to their partly personalized electoral systems, compared to the remaining countries with weak personal vote incentives.

These information indicate good conditions for EU debate in Britain and Germany: relatively high Euroscepticism, institutional capacity, and backbench-friendly agenda-setting conditions. The conditions are unfavorable in the Netherlands and Spain. Austria falls in the middle with lower motivation (compared to UK), institutional capacity (compared to 
Germany), and unfriendly agenda-setting conditions. ${ }^{2}$ This case will help us understand how high the hurdles for backbench attention to the EU are.

The research design considers the notion that there are 'working' and 'talking' parliaments. Figure 1 (b) shows more parliamentary debates in Britain than elsewhere. The workingtalking divide thus suggests most EU debates in the UK, least in Austria, and comparable levels in the remaining countries. Only the expectation of many debates in the UK overlaps with our argument.

Our case selection controls for the possibility that EU debates stem from Eurosceptic challenger parties (e.g. Auel et al., 2015; Hoerner, 2017; Senninger, 2017;). Our countries contain some of Europe's most successful challenger parties in terms of parliamentary seats, in Austria (the Freiheitliche Partei Österreichs, FPÖ, and the Bündnis Zukunft Österreich, BZÖ) and the Netherlands (the Partij voor de Vrijheid, PVV). In the other countries, challengers remain weak (the German Left), emerged only very recently (Germany and Spain) or remain without noteworthy representation (Britain). If challenger parties drive EU debate, Austria and the Netherlands rather than Britain and Germany should see most debates. In the British House of Commons, Eurosceptic opposition might be found within centrist parties. The analysis will examine the link between intra-party dissent and EU debate.

\section{Data}

We code parliamentary debates from 2003-2012. An EU debate is one that would have looked substantially different had the speakers not discussed the EU institutions and policies. We judge debates in these terms after reading the titles and transcripts in the official parliamentary record. Relying on judgment is less reliable than automated coding since it involves a human component as opposed to, for instance, the automatic counting of words in a dictionary. Yet, inter-coder reliability tests yielded reassuring results. ${ }^{3}$ Upon reading the transcript, it is often clear whether a debate is about the EU or not, such as when a European Council meeting or the implementation of an EU law is on the agenda. We see no obvious validity disadvantage to automated coding based on a dictionary (Rauh and De Wilde, 2018). Not only does drawing up the dictionary entail a human component as well, discussions of the validity of automated text analysis also suggest that 'supervised classification methods [require] demonstrating that the classification from machines 
replicates hand coding' (Grimmer and Stewart, 2013: 28). All our data was coded by ourselves and trained assistants.

We record information on policy area and debate initiators. We sort each debate into ten aggregate areas corresponding to divisions in EU policy-making (see the Online appendix). Based on debate title and transcript, we identify the 'initiator' of a debate, the party that has formally put an item forward. Parties sometimes co-initiate a debate in Austria and Germany. We consider parties as initiators of all agenda items they put forward, regardless of co-authors. We thus assume that subscribing to a debate is voluntary and can be conceptualized as a party's choice.

\section{Main variables}

EU debates. We aggregate our dataset to the party level, observed biannually between 2003 and 2012. The summer and winter breaks distinguish phases of parliamentary activity relatively well. New governments often begin after the summer or in January. We also distinguish debates focusing on EU policies from implementation debates. We return to this distinction in the analysis.

European Council priorities. The 'comparative policy agendas' dataset records the percentage of European Council conclusions devoted to a policy (Alexandrova et al., 2014). ${ }^{4}$ We match the 'comparative policy agendas' areas to ours (see the Online appendix).

Adopted EU directives. We obtain information on newly adopted EU directives from an EU law dataset (Duttle et al., 2017). A lag is in order since debate is most likely when these adopted EU directives require implementation. After the adoption of a directive, countries typically have a time window of 1-2 years for implementation. We examined different lags and show the one with the strongest bivariate relationship to EU debates (i.e. a 1-year lag).

EU proposals for directives. Data on proposals for EU directives come from Häge (2011) who extracted these data from the EU's pre-lex archive. We explored different lags. The 3semester lag used here showed the strongest relationships to EU debates.

Core state and regulatory policies. Our data comprises ten policy areas (see the Online appendix). We follow the literature by coding budget and finance, justice and home affairs, 
external and defense, and institutions as core state policies (e.g. Genschel and Jachtenfuchs, 2014a).

Euroscepticism and EU oversight institutions. See section on country cases and note 2.

We control for seat share, government status, election periods, and intra-party disagreement on European integration based on Chapel Hill surveys (Bakker et al., 2015). Due to rather few parties in our data, we refrain from further party-level variables. ${ }^{5}$ The corresponding summary statistics can be found in the Online appendix.

\section{Mapping parliamentary debates}

Our analysis focuses on centrist parties because our theoretical argument applies to them. ${ }^{6}$ The Online appendix shows the EU-related debates of all parties in our data in greater detail. One insight is that British and German parties initiate more EU debates than their counterparts. There also is a lot of variation in partisan debate priorities over time and across policies.

Figure 2 supports our case selection and findings from the literature. Governing parties initiate more EU debates than opposition parties. Semesters with elections see fewer debates (Rauh and De Wilde, 2018). Parties with more seats initiate more debates. There is at best a very mild time trend. Disaggregating into countries does not yield a clear time trend either (not shown). Parties in the British 'talking parliament' initiate more EU debates than parties elsewhere but, beyond the House of Commons, there is no clear pattern. There is a positive correlation between Euroscepticism, EU oversight institutions, and debate. Euroscepticism and EU oversight institutions cannot explain party-level and most temporal differences but still account for $35 \%$ and $6 \%$ of variation in the data. These figures increase to $62 \%$ and $30 \%$ if we aggregate to the country level. There are positive relationships between European Council attention and proposed EU directives and EU debates in a policy area, but not with adopted EU directives. Additional figures of bivariate relationships by country are included in the Online appendix. 


\section{Statistical analysis}

\section{Model}

Since our analysis is observational, we do not make causal claims but we take steps to enhance confidence in the results. Since we expect different results across countries and policies, we present separate analyses for each country and for regulatory and core state policies. Within countries and policy types, the data are nested in parties, policy sub-fields, and years. Rauh and de Wilde (2018) opted for full pooling. The alternatives are no pooling and partial pooling. Scholars caution that no pooling (i.e. fixed effects) overfits the data and depletes variation (e.g. Plümper et al., 2005). Yet, full pooling ignores clustering and likely underfits the data (e.g. McElreath, 2015: 364-370). We opt for the third option, a multilevel model that partially pools information using varying parameters (random effects).

Our data are counts. Compared to the poisson distribution, they are overdispersed. Moreover, in the Netherlands and Spain few EU debates take place. Two standard solutions are: the use of a negative binomial distribution or the inclusion of observation-level random intercepts in a poisson-based multilevel model (McElreath, 2015: 355-386). The latter models individual deviations from the counts expected by a poisson distribution and also absorbs other forms of heterogeneity. We follow this approach since it matches our multilevel structure.

Our model assumes that individual debate observations are drawn from a poisson distribution with central tendency $\lambda$. Through a log-link, lambda is determined by a linear function of the explanatory variables, a global intercept $\alpha$ and observation, party, policy, and year intercepts with variances $\sigma_{i}, \sigma_{\text {party }}, \sigma_{\text {area }}, \sigma_{\text {year }}$. We make mildly regularizing prior assumptions centered on no relationship between the variables and the outcome. Because $\sigma_{i}$ proves hard to estimate efficiently, we apply a more restrictive prior, after having explored less restrictive priors. The Online appendix shows the full model equation.

We fit the model using RStan (Stan Development Team, 2016) and McElreath's (2015) convenience functions. For each model, we ran four Monte Carlo Markov chains of 10.000 steps (including 5000 warm up) each. Trace plots and the potential scale reduction factor suggest that the all chains converged (see the Online appendix for selected trace plots). 
Posterior predictive checks show good model fit (not shown, available in the replication material). ${ }^{7}$

\section{Results}

Figure 3 summarizes mean parameter estimates and 95\%-highest posterior density intervals (HPDI). The coefficients cannot be interpreted directly except in their direction. Interestingly, key findings in the literature do not hold in all contexts. We observe a government bias in regulatory and core state policies, albeit only in Austria, Britain, and Germany. There is no consistent relationship between intra-party dissent and EU debate. Elections seem to depress debate but mainly in core state powers, and not in Britain. The descriptive patterns shown earlier gloss over important contextual differences.

\section{---Figure 3---}

We examine our argument on the basis of Figure 4, which shows median posterior predictions with more and less conservative representations of uncertainty, for an opposition party with the other variables at their means. ${ }^{8}$ In Britain, each party initiates about one extra EU debate per semester and policy under conditions of high European Council attention to a policy area. In Germany, this relationship is similar in core state policies but weaker in regulatory policies. Here the high motivation in the case of the UK seems to drive the effects somewhat more than the high capacity in the case of Germany. In the remaining countries the relationships are mostly flat. The Austrian combination of moderate motivation and capacity does not seem to suffice to encourage systematic attention to the European Council agenda. In the Netherlands, attention to the European Council in core state policies is comparable to that in Germany in regulatory policies. The Spanish data is most difficult to interpret. The relationship of debates and European Council activity could be quite strong but, empirically, there are no observations with many EU debates and uncertainty is large. Uncertainty is generally high, albeit less than in Spain, as parliamentary debates prove hard to predict precisely but the central tendencies are broadly in line with expectations. 
Let us turn to the relationship between EU debates, adopted and proposed directives. Regarding adopted directives, we observe a mildly positive impact on EU debates in regulatory policies in Germany. Otherwise, all relationships are basically flat and highly uncertain (only shown in the Online appendix). Proposed directives (Figure 5) go together with more parliamentary debate on the EU in Germany, in particular in core state policies. In Britain, law proposals coincide with debate in regulatory policies. The pattern is less clear in core state policies. Here the high capacity in the case of Germany seems to drive the effects more than the high motivation in the case of the UK. In all other countries, the relationships are again flat (only shown in the Online appendix).

---Figure 5---

\section{Full models and disaggregated outcomes}

The British and German data contain enough information to enable us to incorporate key case selection variables-Euroscepticism and overall debates-into the analysis. For reasons of space, we show these results in full in the Online appendix and summarize them here. By tendency, Euroscepticism encourages debates although less clearly compared to the differences between countries informing the case selection. Unsurprisingly, EU debates also follow the ebb and flow of the general debate activity of the British and German parliaments. European Council attention matters but, in regulatory policies, not as clearly in Germany. EU law proposals coincide with EU debate in the Bundestag. In regulatory policies, even directives seem to have this effect. In the full models, neither directives nor law proposals clearly lead to more EU debate in Britain. These results rather strengthen the impression that following the legislative process systematically presupposes high institutional capacity.

Finally, our data also identifies whether EU debates focus on the implementation of EU law or rather on EU public policy (see Online appendix). Based on this distinction, we generate two new dependent variables: EU implementation debates and EU policy debates. One would expect that the adoption of EU directives generates implementation rather than policy debates. The European Council and EU proposals for new directives should generate policy debates. Since this reduces the observed debates the results must be taken with caution. Plausible patterns can be observed nonetheless. The European Council agenda 
relates somewhat more to policy than implementation debates in Britain and Germany, even though the differences are small. EU law proposals also encourage policy debates more than implementation debates. Adopted directives rather result in implementation than policy debates in Germany even though, again, the differences are small. It is also interesting to note that the government bias in debates might, at least in Germany, be limited to the implementation of EU law-a task that inevitably falls to the government.

\section{Review of results}

Two key points emerge. First, there are more debates and stronger relationships in Britain and Germany than elsewhere. The mix of institutional capacity, motivation and agendasetting conditions in these countries seems conducive to debate, in line with $\mathrm{H} 3$. The combination of moderate capacity and motivation and unfriendly agenda rules in Austria also encourages debates but less frequently. This combination does not seem to be enough to link debates systematically to EU law-making and policy processes. The hurdles for such systematic parliamentary debate appear to be substantial.

Second, in Britain, where Euroscepticism is high and institutional capacity moderate, the European Council receives somewhat more attention than in Germany. In Germany, the European Council agenda might only matter in core state policies. This supports $\mathrm{H} 2$ insofar that the context of core state policies seems to allow for attention to the European Council in Germany despite the fact that Euroscepticism is 'only' moderate. In Germany, where institutional capacity is high but Euroscepticism moderate, proposed EU directives receive somewhat more attention than in the UK, where law proposals only coincide with debate in regulatory policies. This supports $H 1$ in the sense that the regulatory policy context seems to facilitate British debate despite weaker institutional capacity compared to Germany.

Our hypotheses also warrant critical examination. Where Euroscepticism is high, parliamentarians systematically monitor the European Council's policy agenda in debates regardless of whether it is active in regulatory or core state policies. Where institutional capacity is high, we observe systematic reactions to EU law proposals across policy contexts. Overall, this suggests that, at least in our sample, favorable political context $(H 3)$ can trump disincentives arising from policy context ( $H 1$ \& H2). However, to complicate matters, political context might be policy-specific: high Euroscepticism encourages attention to the European 
Council even in unfavorable policy context (i.e. regulatory policies). High institutional capacity generates attention for law-making in core state policies.

\section{Conclusion}

We began with de Wilde and Raunio's (2015) normative statement that parliamentary debate is most needed and relevant for the public in core state policies and regarding European Council activities. Against this standard, our arguments and evidence are, in principle, optimistic. We see rank-and-file parliamentarians as the main drivers of EU debate. Their political incentives are such that debates should be expected in the countries where citizens care most, on the activities of the European Council, and also on EU lawmaking in the regulatory domains in which it is most prominent. We also stress, however, that institutional resources and agenda-setting rights lend essential support to the debate choices of rank-and-file parliamentarians. We see only partial evidence for the more critical view that there is a government bias and that parliaments avoid EU debates near elections (Rauh and De Wilde, 2018). That popular Euroscepticism depresses debate seems most unlikely given strongly positive cross-national patterns and no obvious trends within countries. Hence, our analysis will likely be welcomed by those who see accountability potential in parliamentary EU debate (Auel and Raunio, 2014b; Auel et al., 2015; Bellamy and Kröger, 2016; Rauh and De Wilde, 2018).

However, one should not ignore another way of looking at our results. For some parliaments, the high motivational and institutional hurdles that stand in the way of EU debates imply little debate (only exceptionally if debate is over-determined by frontbench and backbench interest). Moderate Euroscepticism and institutional capacity in Austria seems to encourage EU debates that, however, do not follow EU policy-making systematically. This is the mirror-image of our findings: namely, that more debates occur on day-to-day EU law-making and European Council meetings where significant extraparliamentary debate already happens (in highly Eurosceptic countries) or where significant intra-parliamentary EU monitoring is in place (through strong oversight institutions).

Finally, regarding the general literature on the 'politicization' of European integration (e.g. De Wilde and Zürn, 2012), our results caution that the parliamentary salience of the EU has not increased. In the parliamentary arenas that we study here, no increase happened since 
the early 2000s and little debate overall takes place in some countries (cf. Rauh and de Wilde, 2018). We only observe increasing debate-for some parties-in budget and finance policies since the onset of the Eurozone crisis (see the Online appendix). Second, the Eurosceptic challenger parties and intra-party dissenters that seem to be important for the extra-parliamentary politicization of the EU are neither essential for nor drivers of parliamentary EU debate.

\section{Acknowledgements}

Replication and supplementary materials are available from the authors and on the European Union Politics website. Jofre Rocabert and Thomas Winzen gratefully acknowledge financial support from the Swiss National Science Foundation in the context of the NCCR Democracy. For their diligent and committed work, we are grateful to our research assistants: Jacolien Cornet, Jana Lipps, Sina Özdemir, Kata Szabó, and Siyana Timcheva. For comments on previous versions, we thank Daniel Finke, Amie Kreppel, Tapio Raunio, Roman Senninger, Frank Schimmelfennig, Thomas Zittel, and the reviewers and editors of European Union Politics, as well as audiences at the ECPR Joint Sessions (Warsaw, 29 March-2 April 2015), the Pademia Annual Conference (Brussels, 19-20 May 2016), the ECPR EU Standing Group (15-18 June 2016), the ECPR Parliaments Standing Group (30 June-2 July 2016 and 29 June - 1 July 2017), and the ECSA Switzerland Annual Meeting (8-9 December 2016).

\section{Notes}

\footnotetext{
${ }^{1}$ The Eurobarometer regularly asks EU citizens whether EU membership is a 'good' or 'bad thing'. We subtract 'good' from 'bad' responses and lag this measure by a year. Regarding the lag, one could argue that politicians rather respond to contemporary public opinion or, as we do, that they update their beliefs about public opinion with delay. In any case, the average, minimum, maximum and standard deviation of contemporary and lagged Euroscepticism are nearly identical. The lagged measure allows us to include 2012 in which the necessary Eurobarometer question was not asked. The index of EU oversight institutions, which Rauh and de Wilde (2018) also employ, captures the strength of parliamentary information rights, processing capacity such as committee structures devoted to the EU, and mandating procedures. Note that, within countries, oversight institutions change only twice, and marginally.

${ }^{2}$ Even though Austria's Euroscepticism has reached Britain's, it is more moderate. Austrian Euroscepticism is not mostly lower and less identity-based. The Eurobarometer shows that only 45 percent of Austrian citizens identified as "exclusively national" in 2010 compared to 63 percent in Britain. British discourse on the EU has been cautious and instrumental throughout post-War history (Jachtenfuchs et al., 1998).
} 
${ }^{3}$ Our reliability tests focus on the EU relevance of a debate. In the Dutch case, we compared our coding to the official parliament assessment and corrected very few discrepancies. The Austrian, German, and Spanish data were coded by the authors. Then a new coder not previously involved and the original coder re-coded a random sample of about 40 plenary meetings with about 5 debates per meeting. In Germany: The original and the re-coded data agree in 92 percent of cases (Cohen's k=0.8, 95\%-Cl: 0.71-0.89). In Austria: 95 percent agreement (Cohen's k=0.88, 95\%-Cl: 0.80-0.93). In Spain: 92 percent agreement (Cohen's k=0.83, 95\%-Cl: 0.660.97). Research assistants coded the British data. We tested inter-coder reliability of the two coders who coded most debates for a random selection of about 40 meetings (186 debates), finding 89 percent agreement (Cohen's k=0.7, 95\%-Cl: 0.59-0.80).

${ }^{4}$ We explored the option to focus on the Council of the EU, not the European Council. Häge (2016) measures the attention to different policies in the working parties of the Council. However, there is little variation in the policy focus of these working parties (see the Online appendix). Focusing on the European Council appears more promising.

${ }^{5}$ Rauh and de Wilde 2018) suggest that parties, which emphasize the EU in their election manifestos, also debate the EU more. However, at face value, there seems to be little empirical plausibility (see the Online appendix).

${ }^{6}$ Our analysis excludes parties that never held more than 5 percent of parliamentary seats. These parties nearly never initiate debates. Regarding the exclusion of challengers, the Online appendix shows that they are by no means exceptional drivers of debate.

${ }^{7}$ For practical reasons, we standardized all variables (expressing the mean as zero and standard deviations as unit changes). Second, note that the replication material includes a re-parameterized version of the model (with the standard deviation imported into the linear model). This re-parameterization is equivalent to the equation here but can be estimated much more efficiently. Third, we observe a small number of divergent iterations in some models (around one percent of iterations), which can be reduced through fine-tuning the target acceptance rate of the Markov chains, albeit at computational costs. Since doing so does not affect the findings and diagnostics are acceptable, we refrain from fine-tuning for the presented models. Finally, we also ran much longer Markov chains without changes in the results.

${ }^{8}$ The distribution of predictions in Spain contains some far outlying predictions, owed to the large uncertainty around some estimates. Therefore, the mean is a poor representation of the central tendency and we show the median. We have also excluded one outlying observation that strongly affected the estimates. The replication material allows re-producing these figures with the outlier. 


\section{References}

Alexandrova P, Carammia M, Princen S, et al. (2014) Measuring the European Council agenda: Introducing a new approach and dataset. European Union Politics 15: 152-167.

André A, Depauw S and Martin S (2016) "Trust Is Good, Control Is Better":Multiparty Government and Legislative Organization. Political Research Quarterly 69: 108-120.

Auel K and Raunio T (2014a) Debating the State of the Union? Comparing Parliamentary Debates on EU Issues in Finland, France, Germany and the United Kingdom. The Journal of Legislative Studies 20: 13-28.

Auel K and Raunio T (2014b) Introduction: Connecting with the Electorate? Parliamentary Communication in EU Affairs. The Journal of Legislative Studies 20: 1-12.

Auel K, Rozenberg O and Tacea A (2015) To Scrutinise or Not to Scrutinise? Explaining Variation in EU-Related Activities in National Parliaments. West European Politics 38: 282-304.

Bakker R, de Vries C, Edwards E, et al. (2015) Measuring party positions in Europe: The Chapel Hill expert survey trend file, 1999-2010. Party Politics 21: 143-152.

Bellamy R and Kröger S (2016) The politicization of European integration: National parliaments and the democratic disconnect. Comparative European Politics 14: 125-130.

Bergman T (1997) National parliaments and EU Affairs Committees: notes on empirical variation and competing explanations. Journal of European Public Policy 4: 373 - 387.

Bickerton CJ, Hodson D and Puetter U (2015) The New Intergovernmentalism: European Integration in the Post-Maastricht Era. Journal of Common Market Studies 53: 703-722.

Carter CA (2001) The Parliament of the United Kingdom: From Supportive Scrutiny to Unleashed Control? In: Maurer A and Wessels W (eds) National Parliaments on their Ways to Europe. Baden-Baden: Nomos, 395-423.

de Ruiter R (2013) Under the radar? National parliaments and the ordinary legislative procedure in the European Union. Journal of European Public Policy 20: 1196-1212.

de Vries CE and Hobolt SB (2012) When dimensions collide: The electoral success of issue entrepreneurs. European Union Politics 13: 246-268.

de Wilde P and Raunio T (2015) Redirecting national parliaments: Setting priorities for involvement in EU affairs. Comparative European Politics.

De Wilde P and Zürn M (2012) Can the Politicization of European Integration be Reversed? Journal of Common Market Studies 50: 137-153.

Duttle T, Holzinger K, Malang T, et al. ( 2017) Opting out from European Union Legislation: The Differentiation of Secondary Law. Journal of European Public Policy 24: 406-428 .

Finke D and Dannwolf T (2013) Domestic scrutiny of European Union politics: Between whistle blowing and opposition control. European Journal of Political Research 52: 715-746.

Franchino F and Hoyland B (2009) Legislative Involvement in Parliamentary Systems: Opportunities, Conflict, and Institutional Constraints. American Political Science Review 103: 607-621.

Gattermann K and Hefftler C (2015) Beyond Institutional Capacity: Political Motivation and Parliamentary Behaviour in the Early Warning System. West European Politics 38: 305-334.

Genschel P and Jachtenfuchs M (2011) How the European Union constrains the state: Multilevel governance of taxation. European Journal of Political Research 50: 293-314.

Genschel P and Jachtenfuchs M (2014a) Beyond the Regulatory Polity? The European Integration of Core State Powers. Oxford: Oxford University Press.

Genschel P and Jachtenfuchs M (2014b) Introduction: Beyond Market Regulation. Analysing the European Integration of Core State Powers. In: Genschel P and Jachtenfuchs M (eds) Beyond the Regulatory Polity? The European Integration of Core State Powers. Oxford: Oxford University Press, 1-23.

Green-Pedersen C (2012) A Giant Fast Asleep? Party Incentives and the Politicisation of European Integration. Political Studies 60: 115-130.

Grimmer J and Stewart BM (2013) Text as Data: The Promise and Pitfalls of Automatic Content Analysis Methods for Political Texts. Political Analysis 21: 267-297.

Häge FM (2011) The European Union Policy-Making dataset. European Union Politics 12: 455-477. 
Häge FM (2016) Political attention in the Council of the European Union: A new dataset of working party meetings, 1995-2014. European Union Politics 17: 683-703.

Herschinger E, Jachtenfuchs $M$ and Kraft-Kasack C (2011) Scratching the heart of the artichoke? How international institutions and the European Union constrain the state monopoly of force. European Political Science Review 3: 445-468.

Hobolt SB and de Vries CE (2015) Issue Entrepreneurship and Multiparty Competition. Comparative Political Studies 48: 1159-1185.

Hoerner JM (2017) Real scrutiny or smoke and mirrors: The determinants and role of resolutions of national parliaments in European Union affairs. European Union Politics 18: 307-322.

Hooghe L and Marks G (2009) A Postfunctionalist Theory of European Integration: From Permissive Consensus to Constraining Dissensus. British Journal of Political Science 39: 1-23.

Hutter S and Grande E (2014) Politicizing Europe in the National Electoral Arena: A Comparative Analysis of Five West European Countries, 1970-2010. Journal of Common Market Studies 52: 1002-1018.

Jachtenfuchs M, Diez T and Jung S (1998) Which Europe?: Conflicting Models of a Legitimate European Political Order. European Journal of International Relations 4: 409-445.

Kinski L (2016) Whom to represent? National parliamentary representation during the eurozone crisis. Journal of European Public Policy: 1-23.

König T, Marbach M and Osnabrügge M (2017) Left/Right or U? Estimating the Dimensionality of National Party Competition in Europe. The Journal of Politics 79: 1101-1105.

Martin S (2014) Committees. In: Martin S, Saalfeld T and Strom K (eds) The Oxford Handbook of Legislative Studies. Oxford: Oxford University Press, 352-370.

McElreath R (2015) Statistical Rethinking: A Bayesian Course with Examples in $R$ and Stan, Boca Raton, FL: Chapman and Hall/CRC.

Plümper T, Troeger VE and Manow P (2005) Panel data analysis in comparative politics: Linking method to theory. European Journal of Political Research 44: 327-354.

Proksch S-O and Slapin JB. (2012) Institutional Foundations of Legislative Speech. American Journal of Political Science 56: 520-537.

Rauh C and De Wilde P (2018) The opposition deficit in EU accountability: Evidence from over 20 years of plenary debate in four member states. European Journal of Political Research 57: 194-216.

Raunio T (2009) National Parliaments and European Integration: What We Know and Agenda for Future Research. The Journal of Legislative Studies 15: 317-334.

Senninger R (2017) Issue expansion and selective scrutiny - how opposition parties used parliamentary questions about the European Union in the national arena from 1973 to 2013. European Union Politics 18: 283-306.

Stan Development Team (2016) RStan: the R interface to Stan. R package version 2.16.2, http://mcstan.org/.

Strøm K (1998) Parliamentary committees in European democracies. The Journal of Legislative Studies 4: 21-59.

Wendler F (2014) Justification and political polarization in national parliamentary debates on EU treaty reform. Journal of European Public Policy 21: 549-567.

Williams CJ (2016) Issuing reasoned opinions: The effect of public attitudes towards the European Union on the usage of the 'Early Warning System'. European Union Politics 17: 504-521.

Winzen T (2012) National parliamentary control of European Union affairs: a cross-national and longitudinal comparison. West European Politics 35: 657-672. 